\title{
FILSAFAT KETUHANAN
}

\author{
Muhammad Noor \\ Politeknik Negeri Tanah Laut \\ E-mail: muhammadnoorpolitala@gmail.com
}

\begin{abstract}
Abstrak
Tuhan dipahami sebagai zat Mahakuasa dan asas dari suatu kepercayaan. Definisi tentang Tuhan tidak memiliki kesepakatan, terdapat berbagai konsep ketuhanan. Dalam pandangan teisme, Tuhan merupakan pencipta sekaligus pengatur segala kejadian di alam semesta. Menurut deisme, Tuhan merupakan pencipta alam semesta, namun tidak ikut campur dalam kejadian di alam semesta. Menurut panteisme, Tuhan merupakan alam semesta itu sendiri. Penganut monoteisme peracya bahwa Tuhan hanya ada satu, serta tidak berwujud (tanpa materi), memiliki pribadi, sumber segala kewajiban moral, dan "hal terbesar yang dapat direnungkan". Akibat konsep ketuhanan yang berbeda-beda itulah, banyak gagasan tentang sosok Tuhan, sifat-sifat yang dimiliki-Nya, bahkan hakikat Tuhan pun terus dipermasalahkan. Siapakah dan bagaimanakah Tuhan terus dicari oleh manusia sebagai fitrah seorang hamba yang akan selalu memerlukan eksistensi tertinggi yang dapat menjadi tempat bertumpu dan berlindung. Filsafat ketuhanan mengajarkan manusia mengenal tuhan melalui akal pikiran semata-mata yanag kemudian kebenarannya didapati sesuai dengan wahyu (kitab suci).Dengan kata lain, bahwa baik agama mauapun filsafat ketuhanan sama-sama bertolak dari pangkalan pelajaran ketuhanan, tetapi jalan yang ditempuh berbeda.
\end{abstract}

Kata kunci: Tuhan, filsafat ketuhanan

\section{PENDAHULUAN}

Tuhan dipahami sebagai zat Mahakuasa dan asas dari suatu kepercayaan. Definisi tentang Tuhan tidak memiliki kesepakatan, terdapat berbagai konsep ketuhanan. Dalam pandangan teisme, Tuhan merupakan pencipta sekaligus pengatur segala kejadian di alam semesta. Menurut deisme, Tuhan merupakan pencipta alam semesta, namun tidak ikut campur dalam kejadian di alam semesta. Menurut panteisme, Tuhan merupakan alam semesta itu sendiri. Penganut monoteisme peracya bahwa Tuhan hanya ada satu, serta tidak berwujud (tanpa materi), memiliki pribadi, sumber segala kewajiban moral, dan "hal terbesar yang dapat direnungkan".

Akibat konsep ketuhanan yang berbeda-beda itulah, banyak gagasan tentang sosok Tuhan, sifat-sifat yang dimiliki-Nya, bahkan hakikat Tuhan pun terus dipermasalahkan. Siapakah dan bagaimanakah Tuhan terus dicari oleh manusia sebagai fitrah seorang hamba yang akan selalu memerlukan eksitensi tertinggi yang dapat menjadi tempat bertumpu dan berlindung. Immanuel Kant menyatakan, bahwa "kebenaran adanya Tuhan adalah kebenaran yang postulat. Yaitu kebenaran tertinggi dalam tingkat kebenaran. Kebenaran tak terbantahkan. Kenenaran yang berada di luar jangkauan indera, akal dan ilmu pengetahuan." Dengan demikian, muncullah sebuah agama yang diaggap menjadi wadah kebenaran akan adanya Tuhan. Agama me-rupakan suatu kepercayaan akan keberadaan suatu kekuatan pengatur supranatural, yang menciptakan dan mengendalikan alam semesta yang selanjutnya dapat disimpulkan, bahwa "agama merupakan suatu kepercayaan akan adanya Tuhan".

\section{PEMBAHASAN}

Filsafat Ketuhanan adalah pemikiran tentang Tuhan dengan pendekatan akal 
budi, maka dipakai pendekatan yang disebut filosofis. Bagi orang yang menganut agama tertentu (terutama agama Islam, Kristen, Yahudi), akan menambahkan pendekatan wahyu di dalam usaha memikirkannya. Jadi Filsafat Ketuhanan adalah pemikiran para manusia dengan pendekatan akal budi tentang Tuhan. Usaha yang dilakukan manusia ini bukanlah untuk menemukan Tuhan secara ab-solut atau mutlak, namun mencari pertim-bangan kemungkinan-kemungkinan bagi ma-nusia untuk sampai pada kebenaran tentang Tuhan.

\section{Pemikir yang mempercayai adanya Tuhan:}

Santo Agustinus (354-430) percaya bahwa Allah ada dengan melihat sejarah dari drama penciptaan, yang melibatkan Allah dan manusia. Allah menciptakan daratan untuk manusia, menciptakan manusia (Adam) yang berdosa melawan Allah. Lalu Adam dan Hawa diusir dari Taman Eden. Kemudian setelah manusia berkembang, mereka berdosa lebih lagi dan dihukum dengan air bah dalam sejarah Nuh. Orangorang Yahudi yang diberikan perjanjian Allah ternyata tidak dapat memeliharanya sehingga dihukum melalui bangsa-bangsa lain. Lalu Allah yang maha kasih menebus manusia melalui Yesus Kristus. Dari sejarah ini Allah dapat selalu ada di tengahtengah manusia. Memang Agustinus adalah Bapa gereja, Uskup dari Hippo yang membela eksistensi Allah dari pandanganpandangan lain yang ingin meruntuhkan paham teisme. Tuhan didefinisikan dari sifat-sifatnya; maha tahu, maha hadir, kekal, pencipta segala sesuatu. Namun lebih lagi, Tuhan bukan ada begitu saja, namun selalu terhubung dalam peristiwa-peristiwa besar manusia.

Thomas Aquinas (1225-1274) menggabungkan pemikiran Aristoteles dengan Wahyu Kristen. Kebenaran iman dan rasa pengalaman bukan hanya cocok, namun juga saling melengkapi; beberapa kebenaran, seperti misteri dan inkarnasi dapat diketahui melalui wahyu, sebagaimana pengetahuan dari susunan benda-benda di dunia, dapan diketahui melalui rasa pengalaman; seperti kesadaran manusia akan eksistensi Allah, baik wahyu maupun rasa pengalaman dipakai untuk membentuk persepsi tentang adanya Allah. Thomas Aquinas terkenal dengan lima jalan (dalam Bahasa Latin; quinque viae ad deum) untuk mengetahui bahwa Allah benar-benar ada.

Jalan 1 adalah gerak, bahwa segala sesuatu bergerak, setiap gerakan pasti ada yang menggerakkan, namun pasti ada sesuatu yang menggerakkan sesuatu yang lain, namun tidak digerakkan oleh sesuatu yang lain, Dialah Allah.

Jalan 2 adalah sebab akibat, bahwa setiap aki-bat mempunyai sebabnya, namun ada penye-bab yang tidak diakibatkan, Dialah sebab pertama, Allah.

Jalan 3 adalah keniscayaan, bahwa di dunia ini ada hal-hal yang bisa ada dan ada yang bisa tidak ada (contohnya adalah bendabenda yang dahulu ada ternyata ada yang musnah, namun ada juga yang dulu tidak ada ternyata sekarang ada), namun ada yang selalu ada (niscaya) Dialah Allah.

Jalan 4 adalah pembuktian berdasarkan derajat atau gradus melalui perbandingan, bahwa dari sifat-sifat yang ada di dunia ( yang baik-baik) ternyata ada yang paling baik yang tidak ada tandingannya (sifat Allah yang serba maha) Dialah Allah.

Jalan 5 adalah penyelenggaraan, bahwa segala ciptaan berakal budi mempunyai tujuan yang terarah menuju yang terbaik, semua itu pastilah ada yang mengaturnya, Dialah Allah.

Filsafat Ketuhanan menurut Rene Descartes (1596-1650) adalah berawal dari fungsi 
iman, yang pada akhirnya berguna untuk menemukan Allah. Tanpa iman manusia cenderung menolak Allah. Ada dua hal yang bisa ditempuh agar $A k u$ sampai pada Allah, 1. sebab akibat, bahwa dirinya sendiri (manusia) pasti diakibatkan oleh penyebab pertama, yaitu Allah. Jalan yang kedua adalah secara ontologis, yang diwarisinya dari Anselmus. Allah yang ada itu tidak mungkin berdiri sendiri, tanpa ada kaitan dengan suatu entitas lain, maka Allah pasti ada dan bereksistensi. Maka Allah yang ada dalam ide Descartes sempurna sudah, bahwa Dia ada dan dapat diandalkan dalam relasi dengan entitas lainnya itu.

Kepercayaan-kepercayaan

tentang

keberada-an Tuhan:

Deisme dianalogikan seperti Tukang Jam, yang menciptakan jam secara teratur dan membiarkannya berjalan sendiri. Deisme adalah pandangan khas tentang Allah di masa Pencerahan, berasal dari deus yang artinya Allah. Namun pandangan ini berbeda dengan teisme, sebab Allah dipercaya hanya pada waktu penciptaan, selanjutnya tidak ber-hubungan dengan dunia lagi karena dunia yang sudah teratur dari semula. Allah dianalogikan seperti pencipta arloji yang bisa berjalan sangat teratur tanpa campur tangan pencipta-nya. Jadi Deisme hanya percaya Tuhan pertama kali, setelah itu dianggap tidak ada. Paham ini dianggap sebagai benih dari munculnya pandangan ateisme yang secara terbuka menyangkal adanya Tuhan. Pandangan yang muncul pada abad 18 di Perancis.

Agnostisisme adalah paham manusia yang tidak mau tahu atau tidak tahu tentang adanya Tuhan. Namun hal ini lebih disebabkan karena kebuntuan pemikiran untuk mendefinisikan Tuhan. Bagi para filsuf ini, Tuhan di berada di luar Jangkauan pemikiran manusia.

Ateisme berarti penyangkalan adanya Allah. Namun arti tentang Allah yang disangkal adanya, tidak sama dengan pandagan semua orang, oleh karenanya arti ateisme berbedabeda juga. Lima model ateisme yang diuraikan Magnis Suseno adalah ateisme dalam diri Ludwig Feuerbach, Karl Marx, Friedrich Nietzsche, Sigmund Freud dan Jean Paul Sartre.

Scientisme merupakan bagian dari Ateisme, sesuai dengan dogma rasionalis, memandang inteligensi manusia sebgai ukuran seluruh inteligibilitas, scientisme membatasi rasio-nalisme sendiri dalam batas-batas pengetahuan saja, sehingga roh manusia sendiri direduksi sampai dimensi ilmiah saja. Segala sesuatu dipandang sebagai obyek yang dapat diukur, bahkan subjek pada akhirnya nanti dibendakan juga. Maka pada akhirnya scientisme menolak metafisika, sehingga apa yang dipikirkan secara metafisik dibendakan begitu saja, dan ini adalah bentuk ateisme. Problem lebih lanjut adalah scientisme melawan pemikiran agama dan iman. Hal ini terjadi pada masa Galilei yang mengemukakan tentang bumi yang diistilahkan geo-sentris.

\section{Konsep Mengenal Tuhan}

\section{Ma'rifatullah}

Ma'rifatullah terbentuk dalam hati manusia secara bertahap. Ambil contoh anak-anak pada awal kehidupannya suka berdusta, bermain dengan tanah, bermain dengan kotoran bahkan dengan barang-barang najis. Seringkali mereka bermain dengan perkara-perkara yang dapat membahayak dirinya. Kadang mengambil barang orang tuanya tanpa ijin. Tak jarang anak-anak menyampaikan informasi yang keliru kepada orang tuanya sehingga menimbulkan pertengkaran dengan orang lain. Namun, tatkala akal mereka sudah terdidik, sudah dihiasi ilmu, mereka meninggalkan semua kebiasaan yang buruk itu sedikit demi sedikit secara bertahap. Hal itu karena didikan orang tua, guru, dan 
lingkungannya. Jadi proses ma'rifatullah itu perlu pendidikan secara bertahap sebagai berikut:

(1) Mengenal Allah melaui sifat-sifat dan nama-nama-Nya. Manusia melalui akalnya dapat sampai kepada Allah, dalam arti memahami wujud Allah dan mengetahui bagaimana mendekatkan diri kepada Allah. Allah yang wajib al-wujud itu memiliki sifat-sifat. Sifat-sifat itu dalam konsep Ahlu al-sunnah wa al-jama'ah ada yang wajib, ada yang mustahil dan ada yang jaiz.

\section{(2) Tauhidullah}

Tauhidullah artinya mengesakan Allah, menafikan segala sesuatu dari orientasi hidup kita selain Allah. Tauhidullah adalah pokok keimanan. Pokok keimanan ini tertuang dalam kalimah tauhid yaitu, "Laailaahaillallah". Maknanya, tidak ada Tuhan selain Allah, tidak ada yang hak disembah selain Allah, tidak ada yang dituju selain Allah, tidak ada yang hak dicintai selain Allah, idak ada yang diminta pertolongan selain Allah.

Kalimat tauhid juga disebut kalimat tayyibah, kalimat salam, kalimat ikhlas. Kalimat tayyibah maknanya kalimat yang baik karena menurut Al-qur'an sendiri lafaz zikir yang paling utama adalah laailaahaillallah. Menurut Nabi kalimat laailaahaillallah adalah kalimat yang paling utama yang diucapkan oleh Nabi Muhammad SAW. dan nabi-nabi sebelumnya. Kalimat salam, maknanya bahwa laailaahaill-allah adalah landasan keselamatan, sebagai-mana nabi menyatakan, "barang siapa yaitu kalimah 'laailaahaillallah' maka dia wajib masuk surga" (hadits). Kalimat ikhlas makna-nya kalimat yang menjadi landasan bagi diterimanya sebuah amal yaitu ikhlas karena Allah. Laailaaha illallah mengandung arti tidak ada yang menjadi tujuan ibadah (tidak ada yang dituju) kecuali Allah.

Mengakui ada ilah selain Allah adalah syirik. Orang yang melakukannya disebut orang musyrik. Beribadah bukan karena Allah adalah syirik. Mengutamakan sesuatu melebihi kehendak Allah adalah syirik. Meminta kepada yang ghaib selain Allah adalah syirik. Syirik adalah kezhaliman yang sangat besar, dan syirik termasuk dosa yang tidak akan diampuni. Bertauhid maknanya mengesakan dan menjadikan Allah di atas segala-galanya.

\section{Pembuktian Keberadaan Allah s.w.t.}

Sebenarnya masalah tentang keberadaan Allah s.w.t. sudahlah nyata, bahkan suatu hakikat yang tidak perlu diragukan lagi persoalannya. Tidak ada jalan untuk mengingkarinya. Persoalan tentang keberadaan Allah s.w.t. adalah terang benderang bagaikan cahaya fajar diwaktu pagi yang cerah. Semua yang ada dilingkungan alam semesta ini pun dapat digunakan sebagai bukti tentang adanya Tuhan (Allah s.w.t.), bahkan benda-benda yang terdapat disekitar alam semesta dan unsur-unsurnya dapat pula mengokohkan atau membuktikan bahwa benda-benda itu pasti ada pencipta dan pengaturnya. Periksalah alam cakrawala yang ada diatas kita, yang di-dalamnya itu terdapat matahari, bulan, bintang, dan sebagainya.

Demikian pula alam yang berbentuk bumi ini dengan segala sesuatu yang ada di dalamnya baik yang berupa manusia, binatang, tumbuh-tumbuhan dan benda padat, juga perihal adanya hubungan yang erat dengan perim-bangan yang pelik yang merapikan susunan diantara alam-alam yang beraneka ragam itu serta yang menguatkan keadaannya masing-masing itu, semuanya tidak lain kecuali merupakan tanda dan bukti perihal wujudnya Allah. Selain menunjukkan adanya Dzat itu juga membuktikan keesaanNya dan hanya Dia sajalah yang Maha Kuasa untuk menciptakannya.

Kiranya tidak terlukis sama sekali dalam akal fikiran siapapun bahwa benda-benda tersebut terjadi tanpa ada yang mengadakan 
atau menjadikan, sebagaimana juga halnya tidak mungkin terlukiskan bahwa sesuatu buatan itu tidak ada yang membuatnya. Oleh sebab itu, manakala sudah tetap bahwa penciptaan alam semesta ini memang karena adanya kesenga-jaan, maka tetap pula lah perihal adanya Tuhan (Allah) sebagai Dzat Maha Pengatur yang bijaksana, Maha Mulia dan Tinggi yakni dari jalan yang sama-sama dapat dirasakan. Dengan demikian tidak ada jalan lain untuk membantah atau mengingkarinya dan ini tepat sekali dengan apa yang difirmankan oleh Allah s.w.t.: "Apakah dalam Dzat Allah masih ada keragu-raguan, yaitu Tuhan Maha Pencipta langit dan bumi?" (S. Ibrahim: 10).

Allah Ta'ala telah berfirman dalam kitabNya yang Agung: "Sesungguhnya Rabb kalian semua adalah Allah yang telah menciptakan langit dan bumi dalam masa enam hari, kemudian Dia bersemayam di atas Arsy. Dia menutupkan malam pada siang yang me-ngikutinya dengan cepat, dan diciptakan-Nya pula matahari, bulan dan bintang-bintang (masing-masing) tunduk pada perintah-Nya, Ingatlah menciptakan dan memerintah itu hanyalah hak Allah, Maha suci Allah Rabb semesta alam." (Al Qur'an Surat: Al A 'raaf:54).

\section{KESIMPULAN}

Filsafat ketuhanan mengajarkan manusia mengenal Tuhan melalui akal pikiran semata-mata yanag kemudian kebenarannya didapati sesuai dengan wahyu (kitab suci). Dengan kata lain, bahwa baik agama mauapun filsafat ketuhanan sama- sama bertolak dari pangkalan pelajaran ketuhanan, tetapi jalan yang ditempuh berbeda.

Masing-masing menempuh cara dan jalannya sendiri, namun keduanya akan bertemu kembali di tempat yang dituju dengan kesimpulan yang sama: Tuhan Ada dan Maha Esa.

\section{DAFTAR PUSTAKA}

http://ALFASAYYIDAHFILSAFATKETUHA NAN.htm

http://filsafatketuhanan.htm

http://filsafatketuhanananagamaaurasujud.htm http://PembuktianAdanyaAllahSWTarrumnyaep py.htm

Ilyas, Yunahar. 2004. Kuliah Aqidah Islam. Yogyakarta: LPPI Universitas Muhammadiyah Yogyakarta.

Sabiq, Sayid. 2002. Aqidah Islam. Bandung: Penerbit Diponegoro.

Syahidin, dkk. 2014. Pendidikan Agama Islam Kontemporer. Bandung: Yayasan Masyarakat Indonesia Baru.

Syaltut, Mahmud. 1994. Aqidah dan Syariah Islam. Jakarta: Bumi Aksara.

Taymiyah, Ibnu. 1983. Aqidah Islam. Ban-dung: Al-Ma'arif. 